\title{
Psychosocial interventions for patients with chronic disease
}

\author{
Hans-Christian Deter
}

\begin{abstract}
Treatment of patients with chronic diseases will be one of the main challenges of medicine in the future. This paper presents an overview of different origins, mechanism, and symptoms necessary for understanding new and different interventions that include a psychosomatic view.

In a psychosomatic therapeutic intervention there are very different targets, such as psychological symptoms, personality traits, attitudes toward disease and life, risk behaviour, and social isolation and as biological targets the change of autonomic imbalance and of the effects of the psycho-endocrinological or psycho-immunological stress responses. And there are also different psychosomatic measures that influence the individual biological,

psychological and sociological targets. There is a need to give different answer to different questions in the field of psychosomatic and behavioral medicine. Comparative effectiveness research is an important strategy for solving some methodological issues. What is the target of treatment for different diseases: Symptom reduction, healing, or limiting progression to the worst case - the death of patients. We know that, the patient-physician relationship is important for every medical/therapeutic action for patients with chronic diseases.

This volume of BioPsychoSocial Medicine will present four different psychosomatic treatment studies from the clinical field in the sense of phase 2 studies: Reports of patients with obesity, anorexia nervosa, chronic somatoform pain and coronary artery disease were presented
\end{abstract}

Keywords: psycho social intervention, concepts, mechanism, efficiacy, eating disorders, pain, coronary artery disease

Bio psycho social medicine integrates different levels of research: The basic sciences focus on psychobiological mechanisms (e.g. psycho-neuroendocrinology, psychoneuroimmunology, psycho-physiology) and psychosomatic correlations. Various pathways have been formulated for different chronic diseases as have strategies for research on interactions between psychic phenomenon and biological functions found in different regions of the body, such as the brain-gut axis and the brain-heart axis. Medicine is not only a diagnostic discipline, but also a research field for medical practice - concentrating on physicians and other health care workers in action with their patients and focusing on the transfer of psychosomatic knowledge gained in the clinical practice of different populations and health care systems.

Correspondence: deter@charite.de

Medical clinic, Psychosomatics, Charité CBF, Hindenburgdamm 30, 12200 Berlin, Germany
Treatment of patients with chronic diseases will be one of the main challenges of medicine in the future because they are very often influenced by psychosomatic or biopsychic factors. Additionally, the psychosomatic origins of many diseases are of interest and important to broader scientific discussion. In a historical view we know that, the patient-physician relationship [1] is especially important for every medical/therapeutic action for patients with chronic diseases. This also is supported by the new placebo literature that explains how the thinking, expectations, and trust of patients in the treatment procedures and in the person of the physician is essential for a positive response, e.g. reducing of symptoms or influencing the healing, of the disease $[2,3]$. This paper presents an overview of different origins, mechanism, and symptoms necessary for understanding new and different interventions that include a psychosomatic view.

Important stressors and risk factors for developing a chronic disease, worsening it, or increasing their
C Biomed Central

(c) 2012 Deter; licensee BioMed Central Ltd. This is an Open Access article distributed under the terms of the Creative Commons Attribution License (http://creativecommons.org/licenses/by/2.0), which permits unrestricted use, distribution, and reproduction in any medium, provided the original work is properly cited. 
chronicity include pathological mechanisms involved in the ethiopathogenesis of disease, psychological mediators, behavioural risk factors, the severity of the disease itself, and their somatic, psychological and sociological effects (Table 1).

Thus, in a psychosomatic therapeutic intervention there are very different targets, such as psychological symptoms, personality traits, attitudes toward disease and life, risk behaviour, and social isolation and as biological targets the change of autonomic imbalance and of the effects of the psycho-endocrinological or psychoimmunological stress responses (Table 2).

However, there are also different psychosomatic measures that influence the individual biological, psychological and sociological targets (Table 3). To date, there are no convincing studies that demonstrate which treatment regimen is helpful for which target in which chronic disease. There are many reports of experiences in the clinical field related to psychosomatic therapeutic support for chronic diseases [4], but in this field the main work lays in front of us. Methodological questions have arisen as to which direction we should take to make the next steps of research. Linda Powell and coworkers [5] gave interesting advice here, comparing the situation with the pharmacological field: Phase 1, phase 2, and phase 3 studies are all helpful and necessary for different tasks in related to this situation of medicine (Table 4). There is a need to give different answer to different questions in the field of psychosomatic and behavioral medicine.

This volume of BioPsychoSocial Medicine will present different studies from the clinical field in the sense of phase 2 studies. Trials of representative chronic diseases using mostly unselected patient samples and special issues, but no randomized controlled trials (RCT) will be reported. Although scientific, clinical, and social medical discussion is important, phase 3 studies give proof of only one very specific and limited treatment effect in one patient group, which does not accurately present the clinical reality and complexity. The floor is open for more phase 1 and phase 2 studies:

1. Some authors focus their intervention on only one important factor - on worrying as a predictor for the development of cardiovascular diseases, such as essential hypertension [6]. This study is an example for focusing a psycho social intervention on a single psychic variable argued as responsible for the development of disease. Here the technique of the behavioral intervention seems very simple but successful in targeting the important influencing factor, such as depression in studies with coronary artery disease [7].

2. Another important aspect is the kind and dosage of drugs used in a psychosomatic therapy. Is it sufficient to treat depression or anxiety in a chronic disease with psychopharmaceuticals alone, or it is necessary to apply additional psychosocial interventions. If so, what amount of psychotherapy is helpful: 10 minutes more conversation with the physician compared to therapy as usual (TAU), or one, two or fifteen hours more than TAU? Moreover, which psychotherapeutic strategy is necessary: relaxation, cognitive, behavioral, or insight therapy, and in which therapeutic setting: individual therapy, group therapy, or a combined therapeutic program in an outpatient or inpatient setting? The basis for all these interactions is a trustful relationship between the patient and therapist, which means that the therapist has to acknowledge the needs and low self esteem of patients and to give hope and trust in the future through professional activity and good relations with the family and friends, all

Table 1 Bio psycho social origins of chronic diseases (e.g coronary heart disease, bronchial asthma, rheumatoid arthritis, inflammatory bowel disease, essential hypertension, atopic dermatitis, diabetes, cancer and others; modified after Orth-Gomér et al 1997)

\begin{tabular}{|c|c|c|c|c|c|c|c|}
\hline & Factor 1 & Factor 2 & Factor 3 & Factor 4 & Factor 5 & Factor 6 & Factor 7 \\
\hline $\begin{array}{l}\text { Psychological } \\
\text { mediators }\end{array}$ & depression & anxiety & hostility & denial & type A & type C & type D \\
\hline $\begin{array}{l}\text { Behavioral risk } \\
\text { factors }\end{array}$ & smoking & $\begin{array}{l}\text { sedentary life } \\
\text { style }\end{array}$ & poor nutrition & alcohol consumption & $\begin{array}{l}\text { suicidal } \\
\text { behavior }\end{array}$ & $\begin{array}{l}\text { no care for the } \\
\text { own person }\end{array}$ & over active \\
\hline $\begin{array}{l}\text { Pathological } \\
\text { mechanism }\end{array}$ & genetic & $\begin{array}{l}\text { autonomic im- } \\
\text { balance }\end{array}$ & $\begin{array}{l}\text { psycho- } \\
\text { immunological path- } \\
\text { ways }\end{array}$ & $\begin{array}{l}\text { psycho- } \\
\text { endocrinological path- } \\
\text { ways }\end{array}$ & inflammation & $\begin{array}{l}\text { lipids/ } \\
\text { glucose }\end{array}$ & coagulation \\
\hline \multicolumn{8}{|l|}{$\begin{array}{l}\text { Severity of } \\
\text { disease }\end{array}$} \\
\hline somatic & $\begin{array}{l}\text { bodily } \\
\text { complaints }\end{array}$ & $\begin{array}{l}\text { bodily } \\
\text { limitations }\end{array}$ & pain & & & & \\
\hline psychological & $\begin{array}{l}\text { psychic } \\
\text { symptoms }\end{array}$ & $\begin{array}{l}\text { chronic } \\
\text { depression }\end{array}$ & suicidal tenden-cies & chronic anxiety & $\begin{array}{l}\text { too many } \\
\text { doctor visits }\end{array}$ & too many drugs & $\begin{array}{l}\text { social } \\
\text { inhibition }\end{array}$ \\
\hline sociological & $\begin{array}{l}\text { low social } \\
\text { functioning }\end{array}$ & social isolation & unable to work & low income & $\begin{array}{l}\text { high } \\
\text { treatment } \\
\text { costs }\end{array}$ & & \\
\hline
\end{tabular}


Table 2 Different psychological, biological and sociological targets forchronic diseases

\begin{tabular}{|c|c|c|c|c|c|}
\hline $\begin{array}{l}\text { Targets of } \\
\text { psychosomatic therapy }\end{array}$ & Target 1 & Target 2 & Target 3 & Target 4 & Target 5 \\
\hline $\begin{array}{l}\text { Psychological } \\
\text { reducing } \\
\text { symptoms }\end{array}$ & depression & anxiety & hostility & pain & \\
\hline $\begin{array}{l}\text { changing } \\
\text { personality } \\
\text { traits }\end{array}$ & self esteem & salutogenesis & type A & type $\mathrm{C}$ & type D \\
\hline $\begin{array}{l}\text { changing attitudes to disease } \\
\text { and life }\end{array}$ & $\begin{array}{l}\text { coping } \\
\text { abilities }\end{array}$ & & & & \\
\hline $\begin{array}{l}\text { Behavioral } \\
\text { changing } \\
\text { behavior }\end{array}$ & $\begin{array}{l}\text { adaption of } \\
\text { illness } \\
\text { behavior }\end{array}$ & $\begin{array}{l}\text { smoking, } \\
\text { alcohol }\end{array}$ & $\begin{array}{l}\text { eating habits } \\
\text { Vegetables and } \\
\text { Low fat }\end{array}$ & $\begin{array}{l}\text { physical } \\
\text { activity }\end{array}$ & \\
\hline $\begin{array}{l}\text { Sociological } \\
\text { Gaining social } \\
\text { support }\end{array}$ & $\begin{array}{l}\text { social } \\
\text { activities }\end{array}$ & $\begin{array}{l}\text { going to } \\
\text { work }\end{array}$ & $\begin{array}{l}\text { better relationship with part } \\
\text { ner/spouse }\end{array}$ & $\begin{array}{l}\text { better } \\
\text { relationship to } \\
\text { other family } \\
\text { members }\end{array}$ & $\begin{array}{l}\text { better } \\
\text { relation } \\
\text { ship to } \\
\text { friends } \\
\text { a. } \\
\text { neighbours }\end{array}$ \\
\hline \multirow[t]{3}{*}{$\begin{array}{l}\text { Biological } \\
\text { targets }\end{array}$} & $\begin{array}{l}\text { harmonize the } \\
\text { autonomic } \\
\text { imbalance }\end{array}$ & $\begin{array}{l}\text { influence } \\
\text { the psycho- } \\
\text { endocrino- } \\
\text { logical } \\
\text { stress response }\end{array}$ & $\begin{array}{l}\text { influence } \\
\text { the psychoen- } \\
\text { docrinological } \\
\text { stress response } \\
\text {-cortisol, catecholamine axis) }\end{array}$ & & \\
\hline & $\begin{array}{l}\text { influence } \\
\text { pathogenic } \\
\text { psychoin- } \\
\text { flammatory } \\
\text { mechanism }\end{array}$ & $\begin{array}{l}\text { influence } \\
\text { pathogenic psycho- } \\
\text { immunologic } \\
\text { mechanism }\end{array}$ & & & \\
\hline & $\begin{array}{l}\text { influence } \\
\text { cerebral regulation } \\
\text { of } \\
\text { the stress } \\
\text { response }\end{array}$ & & & & \\
\hline $\begin{array}{l}\text { Biological } \\
\text { Targets: } \\
\text { Disease } \\
\text { oriented } \\
\text { measurements }\end{array}$ & $\begin{array}{l}\text { asthma: } \\
\text { reduce tendencies } \\
\text { for } \\
\text { attacks of } \\
\text { hyperventi } \\
\text { lation }\end{array}$ & $\begin{array}{l}\text { diabetes: } \\
\text { reduce phases of hyper } \\
\text { and hypo } \\
\text { glycemia }\end{array}$ & $\begin{array}{l}\text { atopic dermatitis: reduce } \\
\text { phases of } \\
\text { cratching }\end{array}$ & $\begin{array}{l}\text { essential hy- } \\
\text { Pretension: } \\
\text { handel } \\
\text { hypertensive } \\
\text { crisis after } \\
\text { emotional } \\
\text { activation }\end{array}$ & \\
\hline $\begin{array}{l}\text { Disease orient- } \\
\text { ted management }\end{array}$ & $\begin{array}{l}\text { information } \\
\text { about disease }\end{array}$ & $\begin{array}{l}\text { make regulatory doctor } \\
\text { visits }\end{array}$ & $\begin{array}{l}\text { behaviour } \\
\text { according disease management } \\
\text { needs }\end{array}$ & $\begin{array}{l}\text { take regulatory } \\
\text { drugs }\end{array}$ & \\
\hline
\end{tabular}

with the intention of minimizing symptoms. Kristina Orth-Gomér showed the usefulness of these activities in their gender segregated groups. Men and women with coronary heart disease seem to do better if they are kept apart in psychotherapeutic groups. It is very impressive to see the way in which such a program of intensive psycho social intervention can influence the psychic and somatic condition of patients.

3 . Therapeutic activity depends not only on the developed health care situation of an individual country, such as Japan, Germany or the US, but also on the research results on special diseases worldwide. Standardization has been done in evidence based medicine (EBM) according psychosocial interventions for different diseases. Great differences in international guideline can be found, i.e. in anorexia nervosa therapeutic measurements between the NICE guidelines of the UK and the German S3 guidelines for eating disorders $[8,9]$.

3. What is the target of treatment for different diseases: Symptom reduction, healing, or limiting progression to the worst case - the death of patients with anorexia nervosa [10]. After a complex, high intensity inpatient therapy, it is important to analyse the conditions that foster a bad outcome and determine the psychosocial factors and psychotherapeutic interventions that improve the prospects for a better long term outcome. In this issue, Laurence Erdur et al present predictors for a dead end after intensive inpatient psychotherapy of Anorexia nervosa. 
Table 3 Different psychological, biological and sociological therapeutic interventions for chronic diseases by general practitioners, medical specialists and psychotherapists

\begin{tabular}{|c|c|c|c|c|c|c|c|}
\hline $\begin{array}{l}\text { Psychosoma- } \\
\text { tic therapy }\end{array}$ & $\begin{array}{l}\text { Individual, } \\
\text { group insight } \\
\text { therapy, }\end{array}$ & $\begin{array}{l}\text { Individual, } \\
\text { group CBT }\end{array}$ & $\begin{array}{l}\text { Relaxa- } \\
\text { tion }\end{array}$ & $\begin{array}{l}\text { Family, } \\
\text { social } \\
\text { therapy }\end{array}$ & $\begin{array}{l}\text { Mentali- } \\
\text { sation }\end{array}$ & $\begin{array}{l}\text { Psycho- } \\
\text { pharma } \\
\text { ceuticals }\end{array}$ & $\begin{array}{l}\text { Other } \\
\text { drug } \\
\text { therapy }\end{array}$ \\
\hline $\begin{array}{l}\text { Psychological } \\
\text { Reducing } \\
\text { of symptoms }\end{array}$ & +++ & +++ & ++ & + & & ++ & + \\
\hline $\begin{array}{l}\text { Changing } \\
\text { personality } \\
\text { traits }\end{array}$ & +++ & ++ & & & & & \\
\hline $\begin{array}{l}\text { Changing atti- } \\
\text { tudes to di- } \\
\text { sease and life }\end{array}$ & ++ & ++ & & & & & \\
\hline $\begin{array}{l}\text { Behavioral } \\
\text { changing } \\
\text { behavior }\end{array}$ & + & +++ & $\begin{array}{l}\text { physical } \\
\text { training } \\
\text { groups }\end{array}$ & + & & & + \\
\hline $\begin{array}{l}\text { Sociological } \\
\text { Gaining social } \\
\text { support }\end{array}$ & ++ & ++ & & +++ & & & \\
\hline $\begin{array}{l}\text { Biological } \\
\text { targets } \\
\text { Harmonize the } \\
\text { autonomic } \\
\text { imbalance }\end{array}$ & + & + & +++ & & & & \\
\hline $\begin{array}{l}\text { Influence } \\
\text { pathogenic } \\
\text { psycho-inflam- } \\
\text { matory } \\
\text { mechanism }\end{array}$ & $+?$ & $+?$ & $++?$ & $?$ & $?$ & $?$ & $?$ \\
\hline $\begin{array}{l}\text { Influence } \\
\text { cerebral re- } \\
\text { gulation of } \\
\text { the stress } \\
\text { response }\end{array}$ & $?$ & $?$ & $?$ & $?$ & $++?$ & $?$ & $?$ \\
\hline $\begin{array}{l}\text { Disease } \\
\text { oriented } \\
\text { measurements }\end{array}$ & + & ++ & ++ & & & + & +++ \\
\hline $\begin{array}{l}\text { Disease orient- } \\
\text { ted management }\end{array}$ & & & & & & & +++ \\
\hline
\end{tabular}

Table 4 Psychosomatic/behavioural research strategies for treatment trials in chronic diseases (according to L. Powell (2010)

\begin{tabular}{ll}
\hline Activities & Targets \\
\hline 1. Identify & mechanism and pacemaker of chronic diseases \\
\hline 2. Evaluate & $\begin{array}{l}\text { effects of different psychosomatic therapeutic } \\
\text { interventions } \\
\text { in chronic diseases in a regular clinical setting } \\
\text { (phase } 1 \text { and phase } 2 \text { studies) }\end{array}$ \\
\hline 3. Evaluate & $\begin{array}{l}\text { therapeutic effects in different diseases in randomized } \\
\text { controlled trials (RCT, phase } 3 \text { studies) }\end{array}$ \\
\hline $\begin{array}{ll}\text { 4. Bring } \\
\text { back }\end{array}$ & $\begin{array}{l}\text { the forthcomings of RCT's in the clinical field. Make } \\
\text { observational studies for all unselected patients }\end{array}$ \\
\hline 5. Specify & $\begin{array}{l}\text { different targets of bio psycho social medicine in chronic } \\
\text { diseases and make again phase } 1 \text { and phase } 2 \\
\text { psychosocial } \\
\text { intervention studies for it }\end{array}$ \\
\hline 6. Compare & $\begin{array}{l}\text { different therapeutic strategies/interventions for } \\
\text { different targets in one chronic disease }\end{array}$ \\
\hline
\end{tabular}

On this point we have to acknowledge the level of evidence based medicine and the importance of randomized controlled trials (RCT) for findings in psychosomatic medicine - the only argument for what counts in the discussion of the somatic disciplines [11]. But, we also have also to differentiate between "phase 2" and "phase 3" studies in a pharmacological sense [4]. In this situation, we need many phase 2 studies to show the effectiveness and not only the efficacy of a targeted psychosocial intervention in a special situation for a special patient group. Comparative effectiveness research is an important strategy for solving these methodological issues [12].

This seems also true in the complex field of patients with pain disorders. Bernd Bergander and collegues show in their article the situation the conditions and the success of a complex inpatient treatment program for these patients. They demonstrated that there are differences between older and younger patients in the concept and 
outcome of treatment. Besides a good relationship between physician and patient, there is a need to understand the individual condition of patients, but it is also an advantage if the physician has good experience in treating this kind of patients over a long period of time and in a somatic and psychological way.

From psycho analytic studies we know that the attachment style of an individual - developed since childhoodis important to the success of a good patient relationship: Sybille Kiesewetter et al showed in their study of patients with obesity the importance of this factor and the helping alliance between patient and therapist in a weight loss program designed to promote a positive change of the body mass index of these patients.

Who is responsible for psychosocial intervention: The physician, the internist, the psychotherapist, the psychologist, the nurse, or the social worker? There is no doubt that every person involved in a psycho social intervention should be well versed in the kind of somatic/pharmacological therapy for this disease. $\mathrm{He} / \mathrm{she}$ should additionally have good communicative ability, a cooperative attachment style, and the capability of understanding patients as biographical, psychological, and sociological beings. This seems to me a non-negligable basis of a psycho social intervention for chronic disease patients. Additionally, the therapist needs knowledge about the risk factors that influence the beginning, course, and end stages of disease as well as the ability to change the thinking and behavior of the patient.

One question remains: All four studies in this volume are without a control group, e.g. phase 2 studies. They show efficiacy in a clinical setting without special selection of patients using standardized measurements and methods. Naturally, there is a need for additional randomized controlled trials, but to date the medical field is very heterogenous in regard to all diseases that are influenced by psycho social factors. Gender, age, severity, and duration of disease and the severity of psychiatric co-morbidity as well as drug intake are additional factors that influence the disease condition and the kind of psychosomatic somato/ psychic mechanism. The field is open for different psycho social interventions on different levels for different diseases, controlling for all the factors mentioned above [13]. As a first step, we must show the effectiveness of such interventions for several diseases - epidemiological and socio medically important and influenced by psychosomatic factors. If we achieve good and impressive results, it will make it possible to change the medical practice in Japan, and all over the world [14]. This volume of BPSMedicine presents four studies to show examples of the ways we can to go in preparing and conducting psycho social medical interventions.
Received: 5 January 2012 Accepted: 31 January 2012

Published: 31 January 2012

\section{References}

1. Deter HC: Towards a new strategy to implement psychosomatic knowledge in medical practice. Biopsychosoc Med 2008, 2:1.

2. Balint M: The doctor, his patient and the Illness. Pitman Medical Publishing London 1964.

3. Zimmermann-Viehoff F: Die Placeboreaktion. Deter HC (Hrsg.) Die Arztpatient Beziehung in der modernen Medizin, Vandenhoeck und Rupprecht, Göttingen 2010.

4. Williams R, Schneiderman N, Relman A, Angell M: Resolved: psychosocial interventions can improve clinical outcomes in organic disease-rebuttals and closing arguments. Psychosom Med 2002, 64(4):564-7.

5. Powell L: Ideas to Interventions: The Process of Developing HealthRelated Behavioral Interventions. APS-preworkshop: Psychosomatic Medicine 2011, 73(3):A-1.

6. Verkuil B, Brosschot JF, Korrelboom K, Reul-Verlaan R, Thayer JF: Pretreatment of worry enhances the effects of stress management therapy: a randomized clinical trial. Psychother Psychosom 2011, 80(3):189-90.

7. Albus C, Beutel ME, Deter HC, Fritzsche K, Hellmich M, Jordan J, Juenger J, Krauth C, Ladwig KH, Michal M, Mueck-Weymann M, Petrowski K, Pieske B, Ronel J, Soellner W, Waller C, Weber C, Herrmann-Lingen C: A stepwise psychotherapy intervention for reducing risk in coronary artery disease (SPIRR-CAD) - rationale and design of a multicenter, randomized trial in depressed patients with CAD. J Psychosom Res 2011, 71(4):215-22.

8. Herpertz S, Hagenah U, Vocks S, v Wietersheim J, Cuntz U, Zeeck A: Clinical practice guideline: The diagnosis and treatment of eating disorders. Dtsch Arztebl Int 2011, 108:678-685, and www.awmf.org/leitlinien/leitlinien Suche/Ess-Störungen.

9. Giel KE, Grob G, Zipfel S: New s3-guideline for the treatment of eating disorders]. Psychother Psychosom Med Psychol 2011, 61(7):293-4, German.

10. Arcelus J, Mitchell AJ, Wales J, Nielsen S: Mortality Rates in Patients With Anorexia Nervosa and Other Eating Disorders A Meta-analysis of 36 Studies. Arch Gen Psychiatry 2011, 68(7):724-731.

11. Wild B, Friederich HC, Gross G, Teufel M, Herzog W, Giel KE, de Zwaan M, Schauenburg H, Schade-Brittinger $C$, Schäfer H, Zipfel S: The ANTOP study: focal psychodynamic psychotherapy, cognitive-behavioural therapy, and treatment-as-usual in outpatients with anorexia nervosa-a randomized controlled trial. Trials 2009, 10:23.

12. Conway PH, Clancy C: Comparative-Effectiveness Research - Implications of the Federal Coordinating Council's Report. N Engl J Med 2009, 361:330.

13. Helfand $M$, Tunis $S$, Whitlock EP, et al: A CTSA agenda to advance methods for comparative effectiveness research. Clin Trans/ Sci 2011, 4:188-98.

14. Deter HC, (Hrsg.): Die Arztpatient Beziehung in der modernen Medizin. Vandenhoeck und Rupprecht, Göttingen 2010.

doi:10.1186/1751-0759-6-2

Cite this article as: Deter: Psychosocial interventions for patients with chronic disease. BioPsychoSocial Medicine 2012 6:2.

\section{Submit your next manuscript to BioMed Central and take full advantage of:}

- Convenient online submission

- Thorough peer review

- No space constraints or color figure charges

- Immediate publication on acceptance

- Inclusion in PubMed, CAS, Scopus and Google Scholar

- Research which is freely available for redistribution

Submit your manuscript at www.biomedcentral.com/submit 